\title{
Підвищення ефективності технічних засобів локального внесення мінеральних добрив при вирощуванні сільськогосподарських культур
}

\author{
В.І. Курлов, Г.В. Фесенко, А.М. Поляков
}

\author{
Луганський національний аграрний університет (м. Старобільськ, Україна) \\ email: ${ }^{1}$ fesenko1491@ukr.net
}

\begin{abstract}
Аналітичними дослідженнями способів внесення в ґрунт мінеральних добрив установлено, що ефективність їх застосування в значній мірі залежить від умов їх внесення, які створюються в відповідних технологіях вирощування сільськогосподарських культур. При цьому із відомих способів внесення мінеральних добрив локальне внесення безпосередньо в ґрунт являється найбільш ефективним з точки зору використання рослинами, а також найменш вразливими для навколишнього середовища. Аналіз пристроїв, які застосовують для локального внесення мінеральних добрив шляхом розсіювання по поверхні ґрунту показав, що при наступному закладенні їх в ґрунт добрива нерівномірно розподіляються по глибині кореневмісного шару, внаслідок чого рослини неповністю засвоюють внесені мінеральні добрива, що знижує ефективність їх застосування. 3 підвищеною ефективністю засвоюються мінеральні добрива внесені безпосередньо в зону кореневмісного шару ґрунту, яке здійснюється при міжрядних обробітках сільськогосподарських культур. Крім того, установлені на серійних ґрунтообробних машинах туковисівні баночно-тарілчасті пристрої наділені активно-примусовою подачею, які допускають внесення мінеральних добрив 3 підвищеною нерівномірністю, що знижує ефективність їх застосування. Разом з цим виявлені шнекові туковисівні пристрої, в яких привалює примусовий характер подачі мінеральних добрив. В результаті конструктивного аналізу таких пристроїв виявлені їх недоліки, що враховані при розробці більш досконалого шнекового пристрою, який забезпечує рівномірний висів мінеральних добрив за рахунок стабілізації переміщення їх стрічками до виходу із розподільчого пристрою з дотриманням заданої норми внесення.
\end{abstract}

Ключові слова: мінеральні добрива, локальне внесення, ефрективність, шнековий пристрій, рівномірність, подача, грунт, секційний кожух.

\begin{abstract}
Аналіз останніх досліджень та публікацій. Врожайність сільськогосподарських культур, являється одним із головних показників ефективності сільськогосподарського підприємства, яка залежить від ряду виробничих фракторів, серед яких провідне місце займає технологія відновлення родючості ґрунту за рахунок внесення різних видів добрив. При цьому більшою швидкодією в порівнянні з органічними добривами наділені мінеральні добрива, які, розчинятись у водному ґрунтовому розчині безпосередньо засвоюються рослинами у вигляді іонів і катіонів [1]. В цілому мінеральні добрива завжди були і нині залишаються для багатьох господарств досить важливою складовою забезпечення високоефективного аграрного виробництва.

Враховуючи агротехнологічні властивості мінеральних добрив, застосування їх при вирощуванні сільськогосподарських культур з кожним роком зростає. Разом з цим ефективність добрив в значній мірі залежить від способу їх внесення та технологічних можливостей тукових машин. Внесення поверхневим способом мінеральних доб-
\end{abstract}

рив туковими машинами вітчизняного виробництва із розкидальними та іншими робочими органами, які широко застосовуються у сільськогосподарських підприємствах, здійснюється нерідко 3 перевищенням агротехнічно допустимої нерівномірності $\pm 25 \%$, що призводить до недобру врожаю і зниженню його якісних показників [2].

Окрім того, при наступному закладенні в грунт мінеральних добрив, відбувається нерівномірний їх розподіл по глибині кореневмісного шару, внаслідок чого культурні рослини неповністю засвоюють внесені мінеральні добрива, що знижує ефективність їх застосування. Це відбувається в результаті того, що при закладенні добрив в грунт, наприклад при оранці, основна їх кількість розміщується на глибині від 9 до $20 \mathrm{~cm}$, внаслідок чого добрива стають малодоступними рослинам на початку їх росту, а при закладенні в Ґрунт культиваторами або дисковими боронами, від 50 до 90\% мінеральних добрив розташовуються в поверхневому шарі ґрунту, який швидко пересихає, що сповільнює подальше використання їх рослинами. 
Поряд із поверхневим внесенням мінеральних добрив і подальшим закладенням в ґрунт, більш ефективним являється локальне внесення, якому присвятили свої наукові дослідження, а саме розробці і впровадженню тукових машин, відомі вчені: П.М. Василенко, П.Т. Бабій, В.І. Якубаускас, А.А. Каликинський, І.С. Вільдфлуш, Г.І. Мангутова, В.Є. Булаєв, В.Є. Белаєв та інші. Разом 3 цим, подальше дослідження локального внесення мінеральних добрив $є$ актуальним в напрямку підвищення ефективності їх використання.

Дослідженнями установлено, що в технологічних процесах землеробства локальне внесення мінеральних добрив, в порівнянні з поверхневим, підвищує їх ефективність до 25\%, що проявляється у збільшенні врожайності сільськогосподарських культур [3]. Разом з цим, локальне внесення мінеральних добрив потребує більш точного внесення заданої їх норми на основі того, що добрива у вигляді стрічок розташовуються на незначній відстані від насіння при посіві, а при міжрядному обробітку ґрунту - від кореневої системи рослин. Виходячи із цього ряд науковців наголошують на проведенні досліджень, спрямованих на розробку технічних засобів з підвищеними якісними показниками локального внесення мінеральних добрив [4]. Аналізуючи технологічний процес внесення локального внесення мінеральних добрив при вирощуванні сільськогосподарських культур установлено, що найбільш поширеними технічними засобами для його здійснення являються ґрунтообробні і посівні машини з установленими на них туковисівними пристроями, які повинні забезпечувати задану норму висіву мінеральних добрив з відхиленням не більше 10\%. При цьому нерівномірність висіву добрив не повинна перевищувати $\pm 10 \%$ [5].

Технічний аналіз ґрунтообробних машин 3 локальним внесенням мінеральних добрив показав, що установлені на них баночно-тарілчасті туковисівні пристрої характеризуються активнопримусовою подачею, в яких переміщення добрив до тарілки здійснюється за рахунок дії сил гравітації. Подальше переміщення добрив в пристрої здійснюється за рахунок обертального руху живильного робочого органу. При цьому примусово переміщуються в напрямку виходу із туковисівного пристрою ті частки добрив, які безпосередньо притискуються до робочого органу, а ті частки, які знаходяться в шарі добрив мають активний характер, що погіршує рівномірність їх подачі [6]. Підвищити якісні показники локального внесення мінеральних добрив можливо, якщо використати принцип саморегуляції розподілу сипких матеріалів в розподільчому робочому органі тукового пристрою з примусовим характером їх переміщення на виході із нього. До таких пристроїв відноситься шнековий робочий орган, в якому кожух виконаний у вигляді секцій і жорстко з'єднаний із шнеком [7]. Відмінною ознакою такого пристрою є заповнення кожуха сипким матеріалом під час обертання розподільчого органу до рівня розташування валу шнека, після чого подальше заповнення кожуха призупиняється і підтримується на цьому ж рівні за рахунок зворотної дії витків шнека на надлишковий матеріал. При цьому сипкий матеріал, опираючись на витки шнека і поверхню кожуха, переміщується по гвинтовому жолобу під дією сили тяжіння $(G)$, реакції зі сторони шнека $\left(R_{1}\right)$, сили реакції зі сторони кожуха $\left(R_{2}\right)$, переносної $\left(I_{\text {пер}}\right)$ та коріолисової $\left(I_{\text {кор }}\right)$ сили інерції [8]. Слід відмітити, що діюча сила $\left(R_{1}\right)$ на частку матеріалу утворена нормальною силою $\left(N_{1}\right)$ і силою тертя $\left(F_{1}\right)$ :

$$
\bar{R}_{1}=\bar{N}_{1}+\bar{F}_{1} .
$$

В свою чергу сила реакції на частки добрива зі сторони кожуха розкладається на нормальну силу $\left(\mathrm{N}_{2}\right)$ і силу тертя $\left(\mathrm{F}_{2}\right)$ :

$$
\bar{R}_{2}=\bar{N}_{2}+\bar{F}_{2} \text {. }
$$

Величина переносної сили $\left(I_{\text {пер}}\right)$, яка діє на частку добрив, знаходиться в прямій залежності від її маси $(m)$ і кутової переносної швидкості обертання $\left(\omega_{\text {пер }}\right)$ шнека робочого органу:

$$
\bar{I}_{\text {пер }}=-m \cdot \bar{\omega}_{\text {пер }} .
$$

Кориолисова сила, що діє в цей час на частку добрива, залежить від її маси $(m)$, кутової переносної швидкості обертання $\left(\omega_{\text {пер}}\right)$ шнека робочого органу і відносної швидкості $\left(v_{\text {відн }}\right)$ її руху:

$$
\bar{I}_{\text {кор }}=-2 m \cdot\left(\bar{\omega}_{\text {пер }} \cdot \bar{v}_{\text {відн }}\right) .
$$

Виходячи із діючих сил на частку мінеральних добрив під час обертання шнекового робочого органу, диференціальне рівняння їх руху у векторній формі набуває наступного вигляду:

$$
\begin{aligned}
& m \bar{a}_{4}=\bar{G}+\bar{N}_{1}+\bar{F}_{1}+\bar{N}_{2}+ \\
& +F_{2}-m \bar{\omega}_{\text {пер }}-2 m \cdot\left(\bar{\omega}_{\text {пер }} \cdot \bar{v}_{\text {відн }}\right) .
\end{aligned}
$$

де $a_{4}$ - прискорення руху частки матеріалу.

На основі саморегуляції розподілу сипких матеріалів і примусового характеру їх переміщення під час руху, розроблена шнекова машина з підвищеними показниками подачі, яка відрізняється установленими між секціями кожуха козирками дахоподібної форми, спрямованими всередину кожуха з відхиленням в бік, протилежний напрямку обертання робочого органу [9]. Процес роботи такої машини починається із заповнення бункера 2 мінеральними добривами і включення приводу шнека 4 через зірочку 13 (рис.1). 
Під час роботи мінеральні добрива із бункера 2 поступають в кожух 3 і шнек 4 своїми витками спрямовує їх у щілини між секціями кожуха 3.
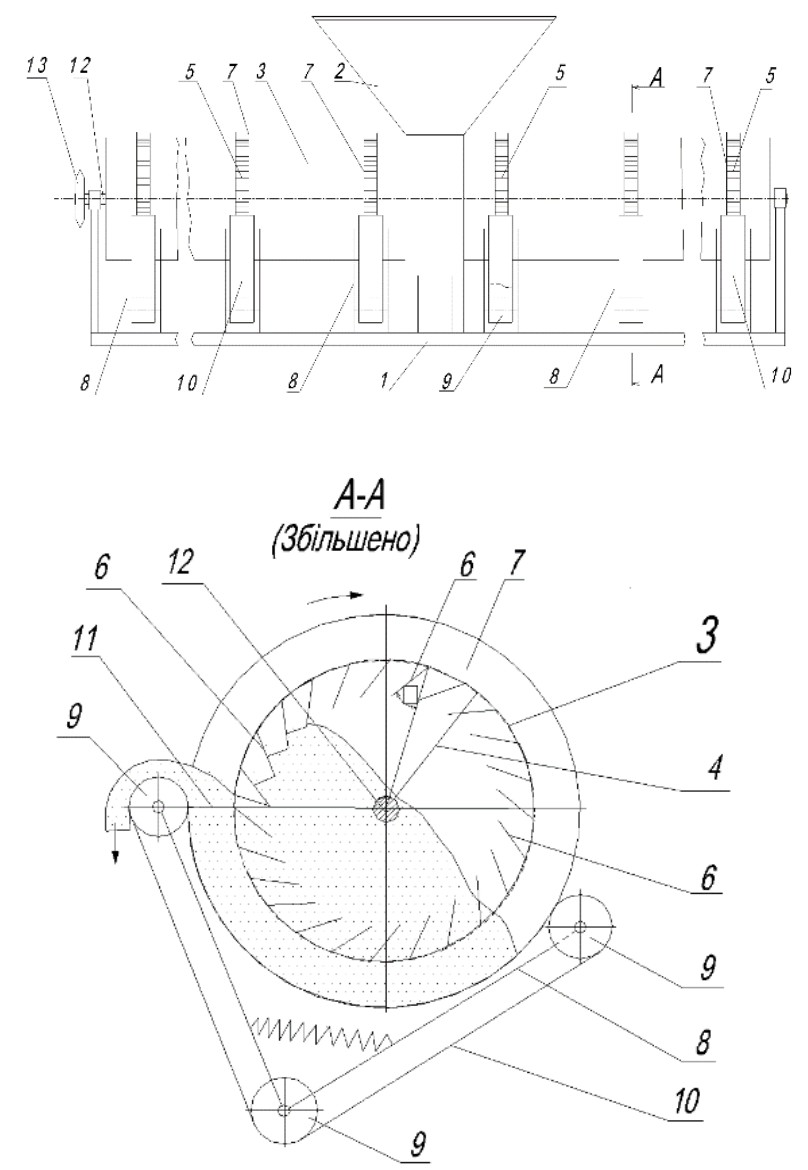

Рис. 1. Схема шнекового пристрою для внесення мінеральних добрив:

1 - рама; 2 - бункер; 3 - кожух; 4 - шнек;

5 - перегородки; 6 - козирки; 7 - диски;

8 - обойма; 9 - ролики; 10 - стрічка;

11 - вихідне вікно; 12 - вісь; 13 - зірочка приводу шнека із кожухом.

При цьому добрива, просипаючись через щілини, поступають на стрічки 10 і заповнюють простір обойм 8, обмежений з бокових сторін кільцевими дисками 7. Подальше переміщення добрив відбувається в напрямку до вихідних вікон 11 за рахунок дії на них з бокових сторін сил тертя кільцевих дисків 7 разом із стрічками 10. В цей час добрива, що знаходяться вище вихідних вікон 11, переміщуються по козиркам 6 із ковзанням під дією сили своєї ваги всередину кожуха 3. Внаслідок цього у вихідних вікнах пристрою привалює примусовий характер переміщення мінеральних добрив, що створює умови для підвищення показників їх внесення в ґрунт.

В результаті подальших творчих пошуків, колективом авторів було знайдено технічне рішення більш досконалої шнекової машини для внесення мінеральних добрив та інших сипких матеріалів, характерною особливістю якої $€$ те, що витки шнека виконані по опуклій лінії повернутій до горловини бункера з відхиленням в напрямку обертання кожуха із шнеком [10]. Конструктивно машина представляє собою установлений на рамі бункер для мінеральних добрив з горловиною, в яку введений багатозахідний шнек із закріпленим на ньому секційним кожухом, секції якого установлені із зазором, в зоні кожного із яких розташований спрямувач у вигляді безкінечної стрічки (рис.2).
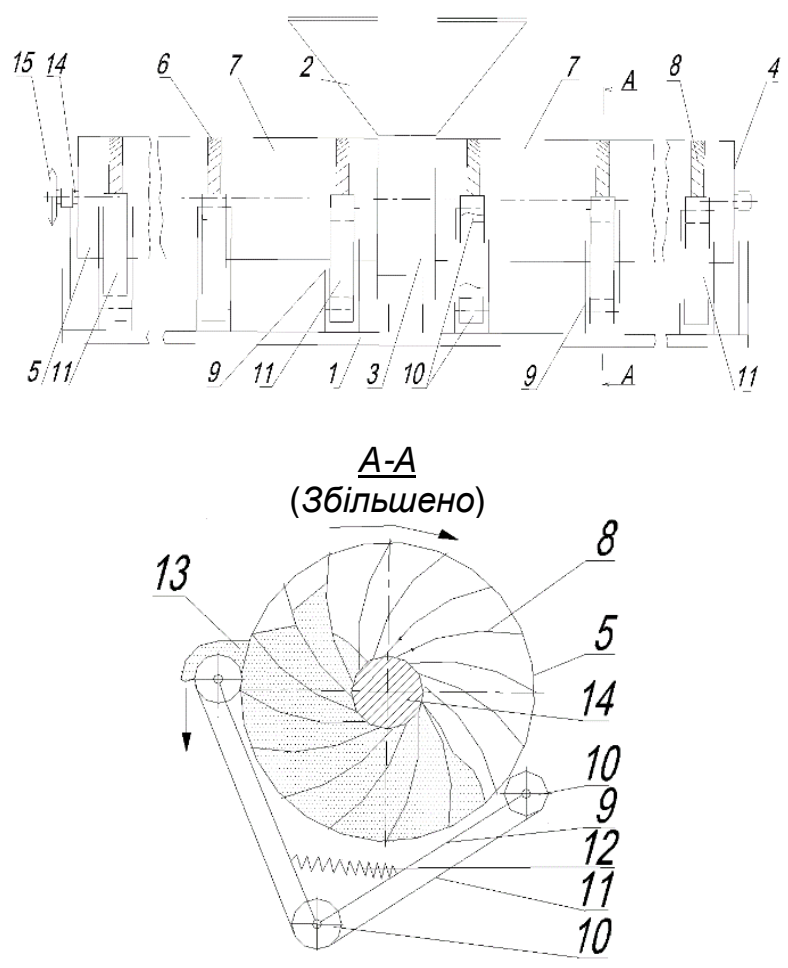

Рис. 2. Схема шнекової машини для внесення в ґрунт мінеральних добрив: 1 - рама; 2 - бункер; 3 - горловина; 4 - розподільчий пристрій; 5 - кожух; 6 - шнек;

7 - секція кожуха; 8 - виток; 9 - спрямував;

10 - ролик; 11 - стрічка; 12 - пружина;

13 - вихідне вікно; 14 - вісь шнека; 15 - зірочка приводу шнека.

Під час роботи такої машини мінеральні добрива із бункера 2 надходять через горловину 3 в кожух 5 до шнека 6, який своїми витками переміщує їх по розподільчому пристрою 4. При цьому добрива просипаються через зазори між секціями кожуха 5 і поступають на стрічки 11 спрямувача 9. Подальше переміщення добрив до вікон 13 розподільчого пристрою 4 відбувається під примусовою дією на них опуклості витків 8 разом із стрічкою 11. Внаслідок цього відбувається стабільне переміщення добрив на виході із вікон 13 
розподільчого пристрою 4, що створює умови рівномірного їх внесення в ґрунт.

Аналізуючи конструктивні особливості відомих пристроїв примусової подачі і виявлені при цьому їх недоліки, з метою підвищення рівномірності внесення мінеральних добрив та інших сипких матеріалів за рахунок стабілізації переміщення їх стрічками до виходу із розподільчого пристрою, знайдено нове технічне рішення у вигляді шнекової машини, яка характерна тим, що стрічки обойми розподільчого пристрою оснащені виступами з проміжками між ними, а зовнішні кромки кільцевих дисків представляють собою радіальні стрижні клиноподібної форми, які спрямовані до стрічки з проникненням в проміжки її виступів [11]. В склад такої машини входить бункер для добрив, розподільчий пристрій у вигляді секційного кожуха, секції якого установлені між собою із зазором і жорстко з'єднані із шнеком, кільцеві диски із зовнішньою кромкою у вигляді стрижнів, обойми охоплені безкінечною стрічкою з виступами (рис.3).
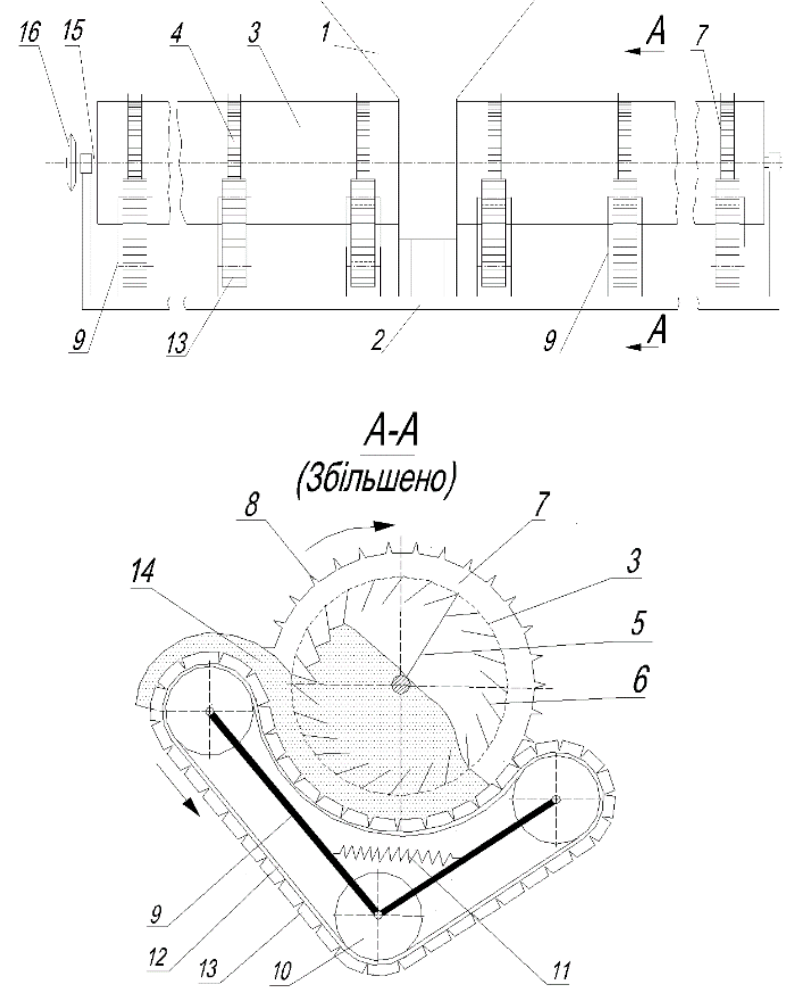

Рис. 3. Схема удосконаленої машини для внесення мінеральних добрив та інших сипких матеріалів: 1 - бункер; 2 - рама; 3 - кожух; 4 - перегородки; 5 - шнек; 6 - козирки; 7 - кільцеві диски; 8 - стрижні; 9 - обойма; 10 - ролик; 11 - стяжна пружина; 12 - стрічка; 13 - виступи стрічки; 14 - вихідне вікно; 15 - вісь шнека; 16 - зірочка приводу валу шнека.
Під час роботи удосконаленої машини мінеральні добрива із бункера 1 самовільно поступають в кожух 3 до шнека 5, які приводяться в обертовий рух від зірочки 16 на осі 15. При цьому добрива переміщуються шнеком 5 по кожуху і потрапляють в зазори між його секціями. Просипаючись через зазори між секціями кожуха 3, добрива поступають на стрічки 12 і заповнюють простір, обмежений з нижньої сторони обоймою 9 i суміжними кільцевими дисками 7. В цей час стрижні 8, взаємодіючи із виступами 13, передають свій обертальний рух від дисків 7 на стрічки 12, що унеможливлює їх проковзування. Подальше переміщення добрив в напрямку вихідних вікон 14 відбувається за рахунок дії на них сил тертя стрічки 12, бокових сторін кільцевих дисків 7 і перегородок 4 зі сторони кожуха 3. Разом з цим, добрива, що знаходяться над вікнами 14, зміщуються козирками 6 всередину кожуха 3, створюючи тим самим сприятливі умови для стабільного виходу добрив із вікон 14. Внаслідок цього під час роботи такої машини забезпечується рівномірний висів мінеральних добрив з дотриманням заданої норми при їх локальному внесенні.

Висновок. В результаті проведених аналітичних досліджень технологій застосування мінеральних добрив при вирощуванні сільськогосподарських культур виявлено, що їх ефективність значно підвищується при внесенні безпосередньо в зону кореневмісного шару ґрунту. Разом $з$ цим серійні туковисівні пристрої, якими обладнані ґрунтообробні машини, не в змозі забезпечити підвищення якісних показників їх внесення в ґрунт ізза привалювання в них активно-примусової подачі. Відомі шнекові пристрої, в яких створюються умови примусової подачі сипких матеріалів, що є необхідною умовою підвищення якісних показників локального внесення мінеральних добрив. На основі цих пристроїв запропоновано нове технічне рішення шнекового тукового пристрою для локального внесення мінеральних добрив з підвищеною рівномірністю подачі за рахунок стабілізації переміщення їх стрічками до виходу із розподільчого пристрою.

\section{Література:}

1. Технологія неорганічних речовин. Ч 3. Мінеральні добрива: навч. посібник / М.Д. Волошин, Я.М. Черненко, А.В. Іванченко, М.А. Олійник. Дніпродзержинськ: ДДТУ, 2016. - 354 с.

2. Сендряков И.Ф., Овчинникова Н.Г., Главацкий Б.А. Влияние качества внесения минеральных удобрений на урожай зерновых культур. // Химия в сельском хозяйстве. 1980. №7. - С. 4 - 7.

3. Пономаренко Н.О. Прийоми локального внесення добрив. Н.О. Пономаренко, В.М. Яропуд, О.В. Зозуляк // Вібрації в техніці та технологіях. - 2016. - № 3 (83). - С. 139 - 142. 
4. Вильдфлуш И.Р. Локальное внесение удобрений - одно из главных средств рационального и экономного использования минеральных удобрений / И.Р. Вильдфрлуш // Агрохимия. 1996. - Вып. 10. - С. 132 - 141.

5. Сільськогосподарські та меліоративні машини: Підручник / Д.Г. Войтюк, В.О. Дубровін, Т.Д. Іщенко та ін.; За ред. Д.Г. Войтюка. - К.: Вища освіта, 2004. - 544 с.

6. Назаров С.И. Обоснование параметров питателей машин для подготовки и внесения минеральных удобрений / С.И. Назаров // Вопросы сельскохозяйственной механики. - 1970. - Т.18, Минск: Урожай. - С. 78 - 212.

7. А. с. 712062 СССР, МПК А01C 15/00. Разбрасыватель сыпучих материалов / Слободюк В.Я., Кириченко В.А., Фесенко Г.В. (СССР).2489348/30-15; заявл.27.05.77; опубл.30.01.80, Бюл. № $4 .-3$ c.

8. Заика П.М. Избранные задачи земледельческой механики : практ. пособие / П.М. Заика. К.: УСХА, 1992. - 512 с.

9. Машина для внесення сипучих мінеральних добрив : пат.94881 Україна: МПК А01С 15/00 / Фесенко Г.В., Сівцов О.В., Сівцов Ю.В., Дуденко В.П.; заявл. 30.09.10; опубл. 10.06.11, Бюл. № 11. - 3 с.

10. Машина для внесення сипучих мінеральних добрив : пат.111908 Україна: МПК А01С 15/00 / Мазоренко Д.І., Мельник В.І., Фесенко Г.В., Романюк А.Г.; заявл. 05.03.15; опубл. 24.06.16, Бюл. № $12 .-4 \mathrm{c}$.

11. Машина для внесення мінеральних добрив та інших сипучих матеріалів : пат.121085 Україна: МПК А01C 15/00 / Фесенко Г.В., Поляков А.М., Курлов В.І.; заявл. 15.11.18; опубл. 25.03.20, Бюл. № 6. - 4 c.

\section{References}

1. Voloshin, M., Chernenko, Y., Ivanchenko, A. and Oliinyk, M., 2016. Tekhnolohiia Neorhanichnykh Rechovyn. Dniprodzerzhynsk: DDTU, p.354.

2. Sendryakov, I., Ovchinnikova, N. and Glavatskiy, B., 1980. Vliyaniye kachestva vneseniya mineralnykh udobrenii na urozhai zernovykh kultur. Khimiya v sel'skom khozyaystve, (7), pp.4 - 7.

3. Ponomarenko, N., Yaropud, V. and Zozulyak, O., 2016. Pryiomy lokalnoho vnesennya dobryv. Vbratsii $\mathrm{v}$ tekhnitsi ta tekhnolohiiakh, 3(83), pp.139 - 142.

4. Vildflush, I., 1996. Lokalnoie vneseniie udobrenii - odno iz glavnykh sredstv ratsionalnogo $i$ ekonomnogo ispol'zovaniya mineralnykh udobrenii. Agrokhimiia, (10), pp.132 - 141.

5. Voytyuk, D., Dubrovin, V. and Ishchenko, T., 2004. Silskohospodarski Ta Melioratyvni Mashyny. Kyiv: Vyshcha osvita, p.544.

6. Nazarov, S., 1970. Obosnovaniie parametrov pitatelei mashin dlia podgotovki i vneseniia mineralnykh udobrenii. In: S. Nazarov, ed., Voprosy selskokhoziaistvennoi mekhaniki, 18th ed. Minsk: Urozhai, pp.78 - 212.

7. Slobodiuk, V., Kirichenko, V. and Fesenko, G., 1980. Razbrasyvatel Sypuchikh Materialov. 2489348/30-15.

8. Zaika, P., 1992. Izbrannyie Zadachi Zemledelcheskoi Mekhaniki. Kyiv: USKHA, p.512.

9. Fesenko, H., Sivtsov, O., Sivtsov, Y. and Dudenko, V., 2011. Mashina Dlia Vnesennia Sypuchykh Mineralnykh Dobryv. 94881.

10. Mazorenko, D., Melnyk, V., Fesenko, H. and Romaniuk, A., 2016. Mashina Dlia Vnesennia Sypuchykh Mineralnykh Dobryv. 111908.

11. Fesenko, H., Poliakov, A. and Kurlov, V., 2020. Mashina Dlia Vnesennia Mineralnykh Dobryv Ta Inshykh Sypuchykh Materialiv. 121085.

\title{
Аннотация
}

\section{Повышение эффективности технических средств локального внесения мине- ральных удобрений при возделывании сельскохозяйственных культур}

\author{
В.И. Курлов, Г.В. Фесенко, А.Н. Поляков
}

Аналитическими исследованиями способов внесения в почву минеральных удобрений установлено, что эфффективность их применения в значительной степени зависит от условий их внесения, которые создаются в соответствующих технологиях выращивания сельскохозяйственных культур. При этом из известных способов внесения минеральных удобрений локальное внесение непосредственно в почву представляется наиболее эффективным с точки зрения использования растениями, а также наименее уязвимыми для окружающей среды. Анализ устройств, которые применяют для локального внесения минеральных удобрений путем рассеивания по поверхности почвы показал, что при следующей закладке их в почву удобрения неравномерно распределяются по глубине корнерасположеного слоя, в результате чего растения не полностью усваивают внесенные минеральные удобрения, что снижает эффективность их применения. С повышенной эффективностью усваиваются минеральные удобрения, внесенные непосредственно в зону расположения корневой системы, которое осуществляется при междурядной обработке сельскохозяйственных культур. Кроме того, установленные на 
серийных почвообрабатывающих машинах туковысевные баночно-тарельчастые устройства наделены активно принудительной подачей, которые допускают внесение минеральных удобрений с повышенной неравномерностью, что снижает эффрективность их применения. Вместе с этим известны шнековые туковысевающие устройства, в которых преобладает принудительный характер подачи минеральных удобрений. В результате конструктивного анализа таких устройств выявлены их недостатки, которые учтены. при разработке более совершенного шнекового устройства, который обеспечивает равномерный высев минеральных удобрений за счет стабилизации перемещения их лентами до выхода из распределяющего устройства с соблюдением заданной нормы внесения.

Ключевые слова: минеральные удобрения, локальное внесение, эффрективность, шнековое устройство, равномерность, подача, почва, секционный кожух.

\title{
Abstract
}

\section{Improving the efficiency of technical means regarding local application of mineral fertilizers in the crop cultivation}

\author{
V.I. Kurlov, G.V. Fesenko, A.M. Poliakov
}

It is set by analytical researches regarding methods of applying mineral fertilizers into the soil, that the efficiency of their application largely depends on the applying terms, which are developed in the proper technologies for crop growing. Moreover, of the known methods of applying mineral fertilizers, local application directly to the soil seems to be the most effective from the point of view of use by plants, as well as the least vulnerable to the environment. An analysis of the devices that are used for local application of mineral fertilizers by dispersion over the soil surface showed that the next time they are laid into the soil, the fertilizers are not evenly distributed along the depth of the root layer, as a result of which the plants do not fully absorb the applied mineral fertilizers, which reduces the efficiency of their use. With high efficiency, mineral fertilizers are absorbed, applied directly to the zone of the root system, which is carried out during inter-row processing of crops. In addition, the mounted fertilizing plate-and flicker distributor installed on serial tillage machines are endowed with actively forced feeding, which allow the application of mineral fertilizers with increased unevenness, which reduces the effectiveness of their use. Along with this, screw fertilizer devices are known, in which the forced nature of the supply of mineral fertilizers predominates. As a result of a constructive analysis of such devices, their disadvantages are identified, which are taken into account, when being developed a more advanced auger device, which ensures even sowing of mineral fertilizers by stabilizing the movement of their fertilizers with tapes until they exit the dispensing device in compliance with a given application rate.

Keywords: mineral fertilizers, local applying, efficiency, screw device, evenness, feeding, soil, sectional casing.

\section{Бібліографічне посилання/ Bibliography citation:Harvard}

Kurlov V.I., Fesenko G.V. and Poliakov A.M. (2020) Improving the efficiency of technical means regarding local application of mineral fertilizers in the crop cultivation. Engineering of nature management, (1(15), pp. 53 - 58.

Подано до редакції / Received: 22.01.2020 